\title{
Liquid-liquid extraction of lipase produced by psychrotrophic yeast Leucosporidium scottii L117 using aqueous two-phase systems
}

\section{Alysson Wagner Fernandes Duarte ${ }^{\mathrm{a}, \mathrm{b}, *}$, André Moreni Lopes ${ }^{\mathrm{c}}$, João Vitor Dutra Molino ${ }^{\mathrm{c}}$, Adalberto Pessoa ${ }^{\mathrm{c}}$, Lara Durães Sette ${ }^{a, b, d}$}

\author{
Division of Microbial Resources, Chemical, Biological and Agricultural Pluridisciplinary Research Center (CPQBA), Campinas State University (UNICAMP), SP, Brazil \\ ${ }^{\mathrm{b}}$ Biotechnology Interunit Post-graduation Program USP/IPT/Butantã, São Paulo, SP, Brazil \\ ${ }^{c}$ Department of Biochemical and Pharmaceutical Technology, School of Pharmaceutical Sciences, University of São Paulo, Brazil \\ ${ }^{\mathrm{d}}$ Department of Biochemistry and Microbiology, University of São Paulo State (UNESP/Rio Claro), SP, Brazil
}

\section{A R T I C L E I N F O}

\section{Article history:}

Received 11 May 2015

Received in revised form 21 September

2015

Accepted 1 October 2015

Available online 9 October 2015

\section{Keywords:}

Downstream processing

Lipase activity

Aqueous two-phase systems

Triton X-114

Polyethylene glycol

\begin{abstract}
A B S T R A C T
Aqueous two-phase systems (ATPS) have been used in biomolecules separation and as an efficient alternative to traditional purification systems for lipases extraction. Here, we investigated the partitioning and recovery of lipase derived from Leucosporidium scottii L117 using ATPS and aqueous two-phase micellar systems (ATPMS). Thus, we evaluated three ATPS: (i) polyethylene glycol (PEG)/phosphate salts and (ii) PEG/polyacrylic acid (NaPA) in different molecular weights (1500, 4000 and $8000 \mathrm{~g} / \mathrm{mol}$ ). (iii) Triton X-114 (TX-114)/McIlvaine buffer pH 7.0 in different conditions $(2.0 \%(\mathrm{w} / \mathrm{w})$ of TX-114 at 25.0 and $28.0^{\circ} \mathrm{C}$ ). The PEG/phosphate and PEG/NaPA systems resulted in a great loss of enzymatic activity; thus these systems do not represent viable alternatives for these lipase extraction. The micellar systems yielded the best results for lipase extraction with enzyme activity balances ranging between $84.7 \%$ and $113.05 \%$. After optimizing the micellar system by experimental design of the partition coefficient of lipase increased by 10.3 -fold $(0.75-7.76)$. Lipase preferentially partitioned into the micelle-rich phase with $K_{\text {Lip }}=7.76, \% \mathrm{REC}_{\mathrm{Bot}}=93.85 \%$ and $\mathrm{PF}=1.2$ at $25.03{ }^{\circ} \mathrm{C}, 5.1 \mathrm{pH}$ and $10.38 \% \mathrm{TX}-114$ and $K_{\text {Lip }}=4.77, \%$ $\mathrm{REC}_{\mathrm{Bot}}=73.53 \%$ and $\mathrm{PF}=1.97$ at $28.00{ }^{\circ} \mathrm{C}, 4.5 \mathrm{pH}$ and $8.0 \% \mathrm{TX}-114$, indicating that the ATPMS represents an alternative to purification/extraction of lipase $L$. scottii L117. A crude lipase extract was also evaluated to define the optimum $\mathrm{pH}$ and temperature. Lipase reached optimal activity at $40{ }^{\circ} \mathrm{C}$, and remained stable in $\mathrm{pH}$ values ranging from $\mathrm{pH} 3.0$ to 8.0 and temperatures from 20.0 to $45.0^{\circ} \mathrm{C}$, with relative residual lipase activity above $80 \%$ after 30 min of incubation.
\end{abstract}

(c) 2015 Elsevier B.V. All rights reserved.

\section{Introduction}

Lipases, or glycerol ester hydrolases (EC 3.1.1.3), form a group of ubiquitous enzymes found in plants, animals and microorganisms. Among the microorganisms, fungi secrete lipases into the fermentation media, making the enzymes easier to isolate [1,2]. Specifically, the extraction of lipases from psychrophilic or psychrotolerant fungi has drawn attention for its high activity at low temperatures [3-5]. High enzymatic activity at low temperatures represents a useful property for many biotechnology applications, including the production of detergents used in cold washing, in agribusinesses, and fermentation processes that require low

* Corresponding author at: Division of Microbial Resources, Chemical, Biological and Agricultural Pluridisciplinary Research Center (CPQBA), Campinas State University (UNICAMP), Av. Alexandre Cazelatto, 999, CEP 13148-218 Paulinia, SP. Brazil.

E-mail address: bioalysson@gmail.com (A.W.F. Duarte). temperatures [5,6]. Moreover, lipases have a wide range of industrial applications, for example, in beverage production, in fat contents reduction from oil effluents, in food organoleptic properties improvement, acting as catalysts for optically active molecules synthesis, and in bioremediation technologies [3,6-8].

Conventional techniques for lipase extraction and purification include ultrafiltration, ammonium sulfate precipitation, and extraction with organic solvents such as cold ethanol and cold acetone. Alternatively, chromatographic techniques such as affinity chromatography, hydrophobic interaction chromatography and ion exchange chromatography are widely employed [9]. These methods have several shortcomings, including low scalability for industrial, elevated costs, and unsatisfactory yield of the purified product [10].

More recently, aqueous two-phase systems (ATPS) have emerged as potential alternatives for the extraction of lipases [11-15]. These liquid-liquid systems perform well in the 
extraction of biologically active molecules including enzymes and other proteins, low-molecular weight compounds such as secondary metabolites and phytochemicals, in addition to cells, organelles, viruses and virus-like particles, with little loss of activity or viability [11,16-21]. Moreover, these systems have advantages compared to the aforementioned methods, including the possibility of large scale extractions, volume reduction, rapid separation with little denaturation, low interfacial tension with rapid mass transfer, and selective separation [16].

The ATPS includes different variations of aqueous systems. One of them is the aqueous two-phase polymer systems (ATPPS) formed when two hydrophilic compounds such as the polymers polyethylene glycol (PEG), polypropylene glycol and dextran (among others), and salts such as phosphates, sulfates and citrates (among others) are mixed above a certain critical concentration resulting in two immiscible phases [22]. ATPS can also be formed with surfactant solutions [16]. In this case, systems are called aqueous two-phase micellar systems (ATPMS), and phase separation results from an increase in temperature, changes in $\mathrm{pH}$, surfactant concentration and addition of salts [10]. Nonionic surfactants, such as octylphenol ethoxylate, Triton ${ }^{\mathrm{TM}} \mathrm{X}-114$ (TX-114) and different alkyl polyoxyethylene surfactants, display such temperaturesensitive phase separation, and can form ATPMS [16,23].

Many parameters affect the performance of ATPS, including the molecular weight and concentration of polymers, the type of surfactant used, $\mathrm{pH}$, temperature, addition of inorganic salts, and others. In addition, inherent characteristics of the target enzyme also affect the system: size, composition dictated by the primary structure, conformation dictated by the secondary, tertiary and quaternary structures, the presence of electric charges, and hydrophobicity $[13,24,25]$. Ooi et al. [10] evaluated the partition of lipase derived from Burkholderia sp. ST8, a proteobacteria, with nonionic surfactant Triton X-114 and Pluronic series (triblock copolymer). These authors observed that the best systems was with Pluronic L81 and not with TX-114.

Furthermore, most of studies of ATPS among microbial lipases has been performed with bacterial lipases $[10,12,13,24]$ and except the lipase produced by Candida spp., few studies have approached with yeast lipases. Therefore, each enzyme will have a better fit with a particular extraction system, and with optimal parameters within that system.

In this work we show that ATPS are an interesting alternative for lipase purification/extraction from Leucosporidium scottii L117 originally isolated from Antarctic marine sediments. Few studies address lipase partitioning in ATPS until the present moment, moreover the extraction of a psychrophilic yeast lipase from an Antarctic microorganism. This study also gather in a single work a broad study of ATPS applicability in the extraction of this interesting molecule, first reported in this study. Besides, our group carried out a deep comparison between ATPPS and ATPMS regarding parameters of the extraction of lipase, and optimized the ATPMS parameters yielding the best results and evaluated the optimum $\mathrm{pH}$ and temperature conditions of this biomolecule.

\section{Material and methods}

\subsection{Materials}

Nonionic surfactant octylphenol ethoxylate (TX-114) and 4morpholineethanesulfonic acid sodium buffer (MES), 3-morpho lino-2-hydroxypropanesulfonic acid buffer (MOPSO), N-[Tris (hyd roxymethyl)methyl]-3-aminopropanesulfonic acid buffer (TAPS) and 3-(Cyclohexylamino)-1-propanesulfonic acid buffer (CAPS) and polyacrylic acid (NaPA) $8000 \mathrm{~g} / \mathrm{mol}(45 \% \mathrm{w} / \mathrm{w})$ were purchased from Sigma-Aldrich ${ }^{\circledR}$ (St. Louis, MO, USA). Polyethylene glycol
(PEG) polymers with molar mass 1500,4000 and $8000 \mathrm{~g} / \mathrm{mol}$, were purchased from Merck ${ }^{\circledR}$ (Hohenbrunn, Germany). All solutions were prepared in Mcllvaine's buffer, $\mathrm{pH}$ 7.0, consisting of $16.4 \mathrm{mM}$ disodium phosphate and $1.82 \mathrm{mM}$ citric acid in water purified by a Millipore Milli-Q system (Bedford, MA, USA). The glassware used was washed in 50:50 ethanol: $1 \mathrm{M}$ sodium hydroxide bath, followed by a $1 \mathrm{M}$ nitric acid bath, rinsed copiously with Milli-Q water and, finally, dried in the oven at $70^{\circ} \mathrm{C}$ for $1 \mathrm{~h}$. All other reagents were of analytical grade and used as received.

\subsection{Sampling and lipase production}

The yeast $L$. scottii L117 used in this study for lipase production was recovered from Antarctic marine sediment during an expedition to Antarctica in the Austral summer (2010) by the Brazilian Antarctic Program team. This strain was chosen based in a study by Duarte et al. [26] about taxonomic identification and bioprospection of enzymes by yeasts from Antarctic environment. For lipase production, the L. scottii L117 was incubated in previously optimized lipase substrate medium containing $6 \mathrm{~mL} \mathrm{~L}^{-1}$ corn steep liquor provided by Corn Products Mogi Guaçú (Mogi Guaçú, São Paulo, Brazil) and $40 \mathrm{~mL} \mathrm{~L}^{-1}$ olive oil, pH 8.0, during $120 \mathrm{~h}$ at $20^{\circ} \mathrm{C}$ under agitation in a rotary shaker $(180 \mathrm{rpm})$. Cell suspension aliquots containing $10^{7}$ cells $/ \mathrm{mL}$ were used to inoculate $50 \mathrm{~mL}$ of the lipase medium in a $125 \mathrm{~mL}$ Erlenmeyer flask. Fermented substrates were centrifuged at $16,000 \mathrm{~g}$ for $10 \mathrm{~min}$ and the supernatant phase was used as the lipase source.

Lipase activity tests were performed using $p$-nitrophenyl palmitate ( $p$-NPP) Sigma-Aldrich ${ }^{\circledR}$ (St. Louis, MO, USA) as substrate. The reaction mixture for lipase quantification contained $3.8 \mathrm{mg}$ of $p$ NPP dissolved in $500 \mu \mathrm{L}$ of dimethyl sulfoxide (DMSO) homogenized in sodium phosphate buffer $(0.05 \mathrm{M}, \mathrm{pH} 8.0$ with Triton X$100[5 \mathrm{~g} / \mathrm{L}])$. The reaction mixture contained $100 \mu \mathrm{L}$ of diluted enzyme with $900 \mu \mathrm{L}$ of substrate $\left(40^{\circ} \mathrm{C}\right.$ for $\left.1 \mathrm{~min}\right)$. The reaction was stopped by heat shock at $90^{\circ} \mathrm{C}$ for $1 \mathrm{~min}$ in water bath, followed by the addition of $1 \mathrm{~mL}$ of saturated solution of sodium tetraborate. Lipase activity was determined by reading absorbance at $405 \mathrm{~nm}$. One unit of enzyme activity (U) was defined as the amount of enzyme capable of releasing $1 \mu \mathrm{mol}$ of $p$-NPP per $\mathrm{mL}$ per min of reaction. All assays were performed in triplicate.

Total protein concentration was determined by the bicinchoninic acid (BCA) method using the Thermo Scientific Pierce BCA Protein Kit (Life Technologies, Carlsbad, CA, EUA) and bovine serum albumin (BSA) as the standard.

\subsection{Partitioning in ATPPS and ATPMS}

\subsubsection{Partitioning in polyethylene glycol/sodium phosphate buffer ATPPS}

The PEG/sodium phosphate buffer extraction systems were prepared from a stock solution of PEG $(50 \% \mathrm{w} / \mathrm{w})$ in sodium phosphate buffer ( $\mathrm{pH} 7.0$ ), prepared with a mixture of monobasic and dibasic sodium phosphate at a ratio of 1.087. All stock solutions were kept at $4{ }^{\circ} \mathrm{C}$. Assays were performed with PEG $(20.0 \% \mathrm{w} / \mathrm{w})$ of different molecular weights and phosphate $(20.0 \% \mathrm{w} / \mathrm{w})$, namely: PEG 1500/phosphate, PEG 4000/phosphate and PEG 8000/phosphate according with others studies with microbial lipase as Ooi et al. [20], Barbosa et al. [13] and Padilha et al. [24].

In every test, the amount of enzyme extract added to the system represented $20 \% \mathrm{w} / \mathrm{w}$ of the total system $(10 \mathrm{~g})$, and the enzyme extract was the last component added. The systems were prepared in $15 \mathrm{~mL}$ graduated tubes sealed with PARAFILM ${ }^{\circledR}$ and kept under orbital agitation at $8 \mathrm{rpm}\left(25^{\circ} \mathrm{C}\right)$ for $1 \mathrm{~h}$. The tubes were then kept in a water bath at $25^{\circ} \mathrm{C}$ until the system had reached equilibrium with complete separation of the phases. The volume of the top and 
bottom phases were recorded and then recovered with disposable syringes.

\subsubsection{Partitioning in polyethylene glycol/polyacrylic acid ATPPS}

We followed the same protocol described in Section 2.3.1 for the preparation of PEG/NaPA systems, with PEG $(20 \% \mathrm{w} / \mathrm{w})$ of different molecular weights and substituting the sodium phosphate buffer for NaPA at a concentration of $20 \% \mathrm{w} / \mathrm{w}$. Tests were also performed with PEG 1500/NaPA, PEG 4000/NaPA and PEG 8000/NaPA. For the NaPA concentration was used phase diagrams presented by Pereira et al. [27].

\subsubsection{Partitioning in Triton $X-114 /$ McIlvaine buffer ATPMS}

The micellar systems consisted of $2.0 \% \mathrm{w} / \mathrm{w}$ nonionic surfactant TX-114 under two temperature conditions, 25.0 and $28.0^{\circ} \mathrm{C}$ as described by Jozala et al. [28]. Reagents were added in the following order: TX-114, followed by Mcllvaine buffer (pH 7.0) and crude enzyme extract (20\%). The tubes were sealed and homogenized for $1 \mathrm{~h}$ on an orbital shaker $(8 \mathrm{rpm})$ and were then placed to rest in a thermoregulated bath at $25.0^{\circ} \mathrm{C}$ or $28.0^{\circ} \mathrm{C}$, until phase separation (approximately $2 \mathrm{~h}$ ).

\subsection{Enzymatic stability in Triton $X-114$}

After defining that the micellar system constituted the best liquid-liquid extraction system, we performed a lipase stability test in nonionic surfactant TX-114. Stability was further examinated for this promising system, to define our workable parameters range. Assays were performed in duplicate at two temperatures $\left(25.0\right.$ and $30.0^{\circ} \mathrm{C}$ ) at different concentrations of TX-114 (2.0$12.0 \% \mathrm{w} / \mathrm{w}$ ) and $\mathrm{pH}$ 7.0. Residual lipase activity was measured every $2 \mathrm{~h}$, for a period of $16 \mathrm{~h}$ after phase separation, and expressed as recovered lipase (\%REC) in the top and bottom phases of the system. Activity balance $\left(\% \mathrm{AB}_{\text {Lip }}\right)$ and partition coefficient $\left(K_{\text {Lip }}\right)$ were also calculated.

\subsection{Optimization of lipase partitioning in Triton X-114/Mcllvaine buffer systems}

After defining the best extraction time in the lipase stability assay, we performed a central composite design (CCD $2^{3}$ ) to optimize extraction conditions. The results were analyzed by response surface using the STATISTICA 7.0 software (STAT SOFT, INC. 1995) [29]. Several factors affect enzymatic extraction by a micellar system, specially extraction temperature, $\mathrm{pH}$ and concentration of the micellar agent.

The independent variables evaluated were: $\mathrm{pH}$ (4.5-7.5), temperature $\left(23.0-33.0^{\circ} \mathrm{C}\right)$ and concentration of TX-114 (4.0-12.0\% $\mathrm{w} / \mathrm{w}$; Table 2). All variables were evaluated at levels designated as -1.68 to +1.68 for the lower and upper points. The central point allowed us to calculate the standard error. The limits of TX-114 were defined from the stability test in TX-114.

\subsection{Effect of $\mathrm{pH}$ and temperature on lipase activity}

Optimal $\mathrm{pH}$ was defined by testing the crude extract in different $50 \mathrm{mM}$ buffers: glycine buffer/ $\mathrm{HCl}(\mathrm{pH} 2.0$ and 3.0), sodium citrate buffer ( $\mathrm{pH} 4.0$ and 5.0), 4-Morpholineethanesulfonic acid sodium buffer (MES) (pH 6.0), 3-Morpholino-2-hydroxypropanesulfonic acid buffer (MOPSO) (pH 7.0), N-[Tris (hydroxymethyl) methyl]3-aminopropanesulfonic acid buffer (TAPS) (pH 8.0 and 9.0) and 3-(Cyclohexylamino)-1-propanesulfonic acid buffer (CAPS) (pH 10.0 and 11.0). Optimal $\mathrm{pH}$ tests were performed at $25.0^{\circ} \mathrm{C}$.

After defining an optimal $\mathrm{pH}$, we evaluated the effects of temperature on lipase activity. Optimal temperature was defined by testing enzyme activity between 5.0 and $65.0^{\circ} \mathrm{C}$ at the previously defined optimal $\mathrm{pH}$. In addition to the univariate analysis, we performed a central composite design $\left(\mathrm{CCD} 2^{2}\right.$ ) to evaluate the synergistic effects of optimal $\mathrm{pH}$ and temperature on lipase activity. The results were analyzed by same software according to Section 2.5. The independent variables were evaluated at levels designated as -1.41 to +1.41 for the lower and upper points and the values were: $\mathrm{pH}(4.0-6.0)$ and temperature $\left(30.0-50.0^{\circ} \mathrm{C}\right)$.

\subsection{Partitioning parameters}

We assessed baseline enzymatic activity $\left(U_{0}\right)$ of the crude lipase source immediately before extraction in the system. For the different liquid-liquid extraction assays, the response variables were:

$U_{\text {totaltop }}=U_{\text {top }} \times V_{\text {top }}$

$U_{\text {totalbot }}=U_{\text {bot }} \times V_{\text {bot }}$

where $U_{\text {top }}$ and $U_{\text {bot }}$ are the units of enzymatic activity in top and bottom phases per volume $\left(\mathrm{U} \mathrm{mL}^{-1}\right)$, respectively.

- Activity balance $\left(\% \mathrm{AB}_{\text {Lip }}\right)$ :

$\% \mathrm{AB}_{\text {Lip }}=\left[\left(U_{\text {totaltop }}+U_{\text {totalbot }}\right) / U_{0}\right] \times 100$

- Enzyme recovered in bottom phase (\%REC $\mathrm{Bot}_{\mathrm{Bot}}$ ):

$\% \mathrm{REC}_{\text {Bot }}=\left(U_{\text {totalbot }} / U_{0}\right) \times 100$

- Enzyme recovered in the top phase $\left(\% \mathrm{REC}_{\mathrm{Top}}\right)$ :

$\% \mathrm{REC}_{\mathrm{Top}}=\left(U_{\text {totaltop }} / U_{0}\right) \times 100$

- Partition coefficient $\left(K_{\text {Lip }}\right)$ :

$K_{\text {Lip }}=\frac{U_{\text {totalbot }}}{U_{\text {totaltop }}}$

- Specific activity $S A=(U / m g$ of protein $)$ :

$\mathrm{SA}=\frac{\mathrm{U} \mathrm{mL}^{-1} \text { of lipase }}{\mathrm{mg} \mathrm{mL}^{-1} \text { of protein }}$

- Purification factor (PF) was calculated as specific activity of each test per specific activity of the crude extract:

$\mathrm{PF}=\frac{\text { Specific activity of assay }}{\text { Specific activity of crude extract }}$

For the selection of the best ATPS, we used, in each test, $2 \mathrm{~mL}$ of a crude source of lipase with activity of $2.7 \mathrm{U} \mathrm{mL}^{-1}$, totaling $5.4 \mathrm{U}$ per test.

\section{Results}

\subsection{Lipase partitioning in ATPPS and ATPMS}

We initially tested the partition of lipase in PEG/salt and PEG/ NaPA systems. In both systems, we measured lipase activity in the top PEG-poor phase but could not detect activity at the bottom phase. The top phase of PEG/salt systems had slightly higher values of enzymatic activity compared to PEG/NaPA systems, regardless of PEG molecular weight. Consequently, recovery (\% $\mathrm{REC}_{\mathrm{Top}}$ ) was also greater in the PEG/salt systems (Table 1 ). Activity balances (\% AB $_{\text {Lip }}$ ) were low in both systems as a result of the lack of activity in the bottom phases.

Next, we evaluated lipase partitions in ATPMS at two temperatures: 25.0 and $28.0^{\circ} \mathrm{C}$. The values obtained for \%REC $48.34 \pm 1.13 \%$ (at $25.0^{\circ} \mathrm{C}$ ) and $67.35 \pm 0.42 \%$ (at $28.0^{\circ} \mathrm{C}$ ), respectively, and the values obtained for $\% \mathrm{REC}_{\text {Bot }}$ were $36.3 \pm 1.2 \%$ (at $25.0^{\circ} \mathrm{C}$ ) and $45.7 \pm 0.5 \%$ (at $28.0^{\circ} \mathrm{C}$ ), respectively. Furthermore, the $\% \mathrm{AB}_{\text {Lip }}$ obtained between $84 \%$ and $113 \%$ demonstrate that the nonionic surfactant TX-114 does not denature $L$. scottii L117 lipase (Table 1).

At $25^{\circ} \mathrm{C}, K_{\text {Lip }}$ was 0.75 , higher than the 0.68 observed at $28.0^{\circ} \mathrm{C}$. This result indicates that, at $25^{\circ} \mathrm{C}$ and $7.0 \mathrm{pH}$, the enzyme has a 
Table 1

Lipase activity on top and bottom phases in three different ATPS (PEG/phosphate, PEG/NaPA and TX-114/buffer systems). Assays performed in duplicate.

\begin{tabular}{|c|c|c|c|c|c|c|c|c|}
\hline \multirow[t]{2}{*}{ Molecular weight (MW) of PEG } & \multicolumn{3}{|l|}{ Top phase } & \multicolumn{3}{|l|}{ Bottom phase } & \multirow{2}{*}{ Activity balance $\left(\% \mathrm{AB}_{\text {Lip }}\right)$} & \multirow[t]{2}{*}{$K_{\text {Lip }}$} \\
\hline & Volume (mL) & Lipase activity $\left(\mathrm{U} \mathrm{mL}^{-1}\right)$ & $U_{\text {totaltop }}(\mathrm{U})$ & Volume (mL) & Lipase activity $\left(\mathrm{U} \mathrm{mL}^{-1}\right)$ & $U_{\text {totalbot }}(\mathrm{U})$ & & \\
\hline \multicolumn{9}{|l|}{ PEG/phosphate } \\
\hline 1500 & 4.7 & 0.44 & 2.08 & 5.3 & 0 & 0 & $38.5 \pm 2.1$ & 0 \\
\hline 4000 & 4.4 & 0.65 & 2.86 & 5.6 & 0 & 0 & $52.9 \pm 3.6$ & 0 \\
\hline 8000 & 4.2 & 0.57 & 2.39 & 5.8 & 0 & 0 & $44.2 \pm 4.2$ & 0 \\
\hline \multicolumn{9}{|l|}{$P E G / N a P A$} \\
\hline 1500 & 3.9 & 0.5 & 1.95 & 6.1 & 0 & 0 & $36.1 \pm 4.3$ & 0 \\
\hline 4000 & 7.3 & 0.29 & 2.11 & 2.7 & 0 & 0 & $39.0 \pm 4.9$ & 0 \\
\hline 8000 & 7.3 & 0.3 & 2.19 & 2.7 & 0 & 0 & $40.5 \pm 1.5$ & 0 \\
\hline \multicolumn{9}{|l|}{$\begin{array}{l}\text { Triton } X-114 \\
T\left({ }^{\circ} \mathrm{C}\right)\end{array}$} \\
\hline 25.0 & 7.9 & 0.33 & 2.61 & 2.1 & 0.93 & 1.96 & $84.7 \pm 2.3$ & 0.75 \\
\hline 28.0 & 8.1 & 0.45 & 3.63 & 1.9 & 1.30 & 2.47 & $113.05 \pm 0.9$ & 0.68 \\
\hline
\end{tabular}

Table 2

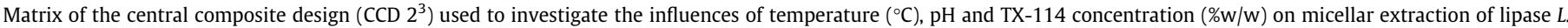
scottii L117.

\begin{tabular}{|c|c|c|c|c|c|c|c|c|c|c|c|}
\hline Assays & $T\left({ }^{\circ} \mathrm{C}\right)$ & $\mathrm{pH}$ & $\begin{array}{l}\mathrm{TX}-114 \\
(\% \mathrm{w} / \mathrm{w})\end{array}$ & $U_{\text {totaltop }}$ & $U_{\text {totalbot }}$ & $\begin{array}{l}\text { Recovered top } \\
\left(\% \text { REC }_{\text {Top }}\right)\end{array}$ & $\begin{array}{l}\text { Recovered } \\
\text { bottom } \\
\left(\% \text { REC }_{\text {Bot }}\right)^{a}\end{array}$ & $\begin{array}{l}\text { Activity } \\
\text { balance } \\
\left(\% \mathrm{AB}_{\mathrm{Lip}}\right)\end{array}$ & $\begin{array}{l}\text { Partition } \\
\text { coefficient } \\
\left(K_{\text {Lip }}\right)\end{array}$ & $\begin{array}{l}\text { Specific activity Bot } \\
\text { (U/mg of protein) }\end{array}$ & $\begin{array}{l}\text { Purification } \\
\text { factor (PF) }\end{array}$ \\
\hline 1 & $-1(25.03)$ & $-1(5.1)$ & $-1(5.62)$ & 1.275 & 2.631 & 23.62 & 48.73 & 72.35 & 2.06 & 1.22 & 1.17 \\
\hline 2 & $1(30.97)$ & $-1(5.1)$ & $-1(5.62)$ & 1.696 & 2.105 & 31.42 & 38.98 & 70.40 & 1.24 & 1.30 & 1.26 \\
\hline 3 & $-1(25.03)$ & $1(6.9)$ & $-1(5.62)$ & 2.322 & 0.728 & 43.01 & 13.49 & 56.50 & 0.31 & 0.82 & 0.79 \\
\hline 4 & $1(30.97)$ & $1(6.9)$ & $-1(5.62)$ & 2.173 & 0.556 & 40.25 & 10.3 & 50.55 & 0.25 & 0.39 & 0.37 \\
\hline 5 & $-1(25.03)$ & $-1(5.1)$ & $1(10.38)$ & 0.652 & 5.067 & 12.08 & 93.85 & 105.93 & 7.76 & 1.24 & 1.20 \\
\hline 6 & $1(30.97)$ & $-1(5.1)$ & $1(10.38)$ & 0.521 & 3.402 & 9.64 & 63.01 & 72.65 & 6.53 & 1.25 & 1.21 \\
\hline 7 & $-1(25.03)$ & $1(6.9)$ & $1(10.38)$ & 2.067 & 3.566 & 38.29 & 66.05 & 104.35 & 1.72 & 0.79 & 0.76 \\
\hline 8 & $1(30.97)$ & $1(6.9)$ & $1(10.38)$ & 1.932 & 2.042 & 35.78 & 37.83 & 73.61 & 1.05 & 1.49 & 1.44 \\
\hline 9 & $-1.68(23.0)$ & $0(6.0)$ & $0(8.0)$ & 1.06 & 3.976 & 19.63 & 73.63 & 93.27 & 3.75 & 1.67 & 1.61 \\
\hline 10 & $1.68(33.0)$ & $0(6.0)$ & $0(8.0)$ & 1.307 & 1.791 & 24.21 & 33.18 & 57.39 & 1.37 & 0.69 & 0.66 \\
\hline 11 & $0(28.0)$ & $\begin{array}{l}-1.68 \\
(4.5)\end{array}$ & $0(8.0)$ & 0.832 & 3.97 & 15.41 & 73.53 & 88.94 & 4.77 & 2.04 & 1.97 \\
\hline 12 & $0(28.0)$ & $1.68(7.5)$ & $0(8.0)$ & 1.186 & 1.857 & 21.97 & 34.4 & 56.37 & 1.56 & 2.06 & 1.99 \\
\hline 13 & $0(28.0)$ & $0(6.0)$ & $\begin{array}{l}-1.68 \\
(4.0)\end{array}$ & 2.242 & 1.509 & 41.52 & 27.95 & 69.47 & 0.67 & 1.15 & 1.10 \\
\hline 14 & $0(28.0)$ & $0(6.0)$ & $1.68(12.0)$ & 0.363 & 2.798 & 6.73 & 51.82 & 58.55 & 7.69 & 0.92 & 0.88 \\
\hline 15 & $0(28.0)$ & $0(6.0)$ & $0(8.0)$ & 1.166 & 2.765 & 21.6 & 51.22 & 72.82 & 2.37 & 1.56 & 1.50 \\
\hline 16 & $0(28.0)$ & $0(6.0)$ & $0(8.0)$ & 1.233 & 2.775 & 22.84 & 51.39 & 74.22 & 2.25 & 1.55 & 1.50 \\
\hline 17 & $0(28.0)$ & $0(6.0)$ & $0(8.0)$ & 1.196 & 2.71 & 22.16 & 50.19 & 72.34 & 2.26 & 1.60 & 1.55 \\
\hline
\end{tabular}

a In all assays the bottom phase was clear and transparent and the top phase was characterized by yellow color and turbid aspect.

slightly greater preference for the micelle-rich phase than at the lower temperature.

\subsection{Enzymatic stability in Triton $X-114$}

After establishing that ATPMS constitute the best systems for lipase extraction, we tested enzymatic stability, defined as \% $\mathrm{AB}_{\mathrm{Lip}}$, at two different temperatures, 25.0 and $30.0^{\circ} \mathrm{C}$, at different times after phase separation $(2,4,6,8,12$ and $16 \mathrm{~h})$, and different TX114 concentrations $(2.0 \%, 4.0 \%, 6.0 \%, 8.0 \%, 10.0 \%$ and $12.0 \%)$. The highest \% $\mathrm{AB}_{\text {Lip }}$ value $(99.60 \%)$ was reached at $25.0{ }^{\circ} \mathrm{C}$, after $4 \mathrm{~h}$ in $10.0 \%$ of TX-114, whereas the lowest value of $38.3 \%$ was also reached at $25.0{ }^{\circ} \mathrm{C}$, after $2 \mathrm{~h}$ in $4.0 \%$ of TX-114. However, these values varied with time, and $\% \mathrm{AB}_{\mathrm{Lip}}$ tended to remain higher for longer at a temperature of $30.0^{\circ} \mathrm{C}$. In general, even high concentrations of TX-114, for the longer periods tested, at either temperature, did not strongly denature lipase.

$K_{\text {Lip }}$ values were evaluated under the same conditions described for \% $\mathrm{AB}_{\text {Lip }}$ partitioned to top and bottom phases depending on the concentration of TX-114 and time of extraction. At $25.0^{\circ} \mathrm{C}, K_{\mathrm{Lip}}$ was highest at TX-114 concentrations of $8.0 \%$ (2.2 at $4 \mathrm{~h}$ ) and $10.0 \%$ (10.6 at $2 \mathrm{~h}$ ). On the other hand, $K_{\text {Lip }}$ values at $30.0^{\circ} \mathrm{C}$ were lower than those obtained at $25.0^{\circ} \mathrm{C}$. Again, the highest values coincided with higher TX-114 concentrations of $8.0 \%(1.53$ at $8 \mathrm{~h}$ ) and $10.0 \%$ (3.55 at $2 \mathrm{~h}$ ). The lowest $K_{\text {Lip }}$ values at 25.0 and $30.0^{\circ} \mathrm{C}$ were, respectively, 0.40 at $2.0 \%$ after $16 \mathrm{~h}$, and 0.33 at $4.0 \%$ after $6 \mathrm{~h}$. In these cases, enzymes preferentially partitioned into the micellepoor top phase, explaining the $K_{\text {Lip }}<1.0$. Overall, with increasing time, $K_{\mathrm{Lip}}$ tended to decrease, indicating that enzyme concentrations increased in the top phase (Fig. $1 \mathrm{~B}$ and $\mathrm{E}$ ).

The $\% \mathrm{REC}_{\mathrm{Bot}}$ at $25.0{ }^{\circ} \mathrm{C}$, between $2.0 \%$ and $8.0 \%$ of $\mathrm{TX}-114$, showed values ranging from $19.50 \%$ ( $4.0 \%$ at 2 h) to $58.10 \%(8.0 \%$

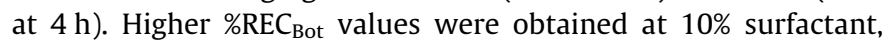
varying between $43.80 \%(12 \mathrm{~h})$ and $83.60 \%(4 \mathrm{~h})$. In the range between $4.0 \%$ and $8.0 \%$ of TX-114, \% $\mathrm{REC}_{\mathrm{Bot}}$ values were relatively higher at 30.0 than at $25.0^{\circ} \mathrm{C}$. In this range, \%REC $\mathrm{Bot}_{\text {voried from }}$ $23.40 \%(6.0 \%$ at $12 \mathrm{~h})$ to $58.80 \%(8.0 \%$ at $8 \mathrm{~h})$. Again, at $10.0 \% \mathrm{TX}-$ 114 , \% $\mathrm{REC}_{\mathrm{Bot}}$ values were higher, ranging between $36.30 \%$ ( $\left.6 \mathrm{~h}\right)$ and $70.50 \%(2 \mathrm{~h})$, but remained lower than the values obtained at the same concentration of TX-114 at $25.0^{\circ} \mathrm{C}$ (Fig. 1C and F).

\subsection{Optimization of lipase partitioning in ATPMS}

Based on $\% \mathrm{AB}_{\text {Lip }}$ results, we defined an optimal extraction time of $6 \mathrm{~h}$ at $25.0^{\circ} \mathrm{C}$ and established that lipase remains stable at high concentrations of TX-114 (4.0-12.0\%), we then optimized the vari- 
ables: $\mathrm{pH}, \mathrm{TX}-114$ concentration and extraction temperature using an experimental design. According to optimization results, assay 5 (Table 2) showed the best recovery on the bottom phase (93.85\%), a $K_{\mathrm{Lip}}=7.76$, and $\mathrm{PF}=1.2$. Assay 11 also displayed good overall results with $\% \mathrm{REC}_{\mathrm{Bot}}=73.53 \%, K_{\mathrm{Lip}}=4.77$ and $\mathrm{PF}=1.97$. In all assays bottom phase (micelle-rich) had a clear and transparent aspect and top phase (micelle-poor) was characterized by a yellow color, with turbid aspect (Fig. 2).

The three evaluated variables had statistically significant effects $(p<0.05)$ on \% REC ${ }_{\text {Bot, }}$, where TX-114 concentration had a positive effect, and extraction temperature and $\mathrm{pH}$ had negative effects (Supplementary material: Tables 4 and 5). Statistical significance of the analyses was confirmed by $F$ test (ANOVA). The $F$ test value of 25.65 for the regression was highly significant, i.e., higher than the tabulated value of $3.41(p<0.05)$, and the model fitted well with the data $\left(R^{2}=85.5 \%\right)$. Thus, we assumed the equation of model DOE [\%REC $\mathrm{Bot}=48.2088-10.2571$ (Temperature ${ }^{\circ} \mathrm{C}$ ) $13.3852(\mathrm{pH})+13.8765(\mathrm{TX}-114)]$ had good predictive value and used it to generate the response surface shown in Fig. 3. The optimization of lipase extraction was confirmed at condition described in assay 11 (Table 2) and showed in Fig. 2.

Based on the statistical results, when the response variable was the $K_{\mathrm{Lip}}$, in addition to the three variables that were significant for $\% \mathrm{REC}_{\mathrm{Bot}}$, the TX-114 concentration in quadratic form, as well as the $\mathrm{pH}$ and TX-114 concentration, were statistically significant $(p<0.1$; Supplementary material: Table 6$)$. Similarly to what was observed with the response variable $\% \mathrm{REC}_{\mathrm{Bot}}, \mathrm{pH}$ and temperature had negative effects and TX-114 concentration had a positive effect on $K_{\text {Lip. }}$. Statistical significance of the analyses (Supplementary material: Table 7 ) was confirmed by $F$ test (ANOVA). The $F$ test value of 33.78 for the regression was significant, i.e., greater than the tabulated value of 2.45; and the model fitted well with the data $\left(R^{2}=93.89 \%\right)$. Thus, the equation of model DOE $\left[K_{\mathrm{Lip}}=2.41091-\right.$ 0.49678 (temperature ${ }^{\circ} \mathrm{C}$ ) $-1.44041(\mathrm{pH})+1.83173$ (TX-114) $\left.+0.4855(\mathrm{TX}-114)^{2}-1.0975(\mathrm{pH} \times \mathrm{TX}-114)\right]$ had good predictive value and used it to generate response surfaces shown in Fig. 4.

On the other hand, when we used the PF as the response variable, the variable TX-114 concentration in quadratic form was statistically significant $(p<0.1)$, but the regression coefficient was low $R^{2}=64.0 \%$ A similar result was observed when the variable response was \% $\mathrm{AB}_{\mathrm{LIP}}$, on which temperature, $\mathrm{pH}$ and TX-114 concentration had statistically significant effects in linear form $(p<0.05)$, albeit with a low regression coefficient $\left(R^{2}=57.83 \%\right)$. Both variables responded positively to TX-114 concentration and negatively to $\mathrm{pH}$ and temperature (Fig. 5).

\subsection{Effects of $\mathrm{pH}$ and temperature on lipase activity}

We identified optimal $\mathrm{pH}$ and temperature for the lipase activity of $L$. scottii L117. The enzyme had acid lipase characteristics, displaying optimal activity levels at $\mathrm{pH} 5.0$, with relative activities of $50.1 \pm 6.36 \%$ and $86.46 \pm 4.9 \%$ at $\mathrm{pH} 4.0$ and 6.0 , respectively. In spite of the psychrotrophic nature of $L$. scottii L117, the lipase isolated from it remains active between $5.0^{\circ} \mathrm{C}$ and $65.0^{\circ} \mathrm{C}$, reaching (a)

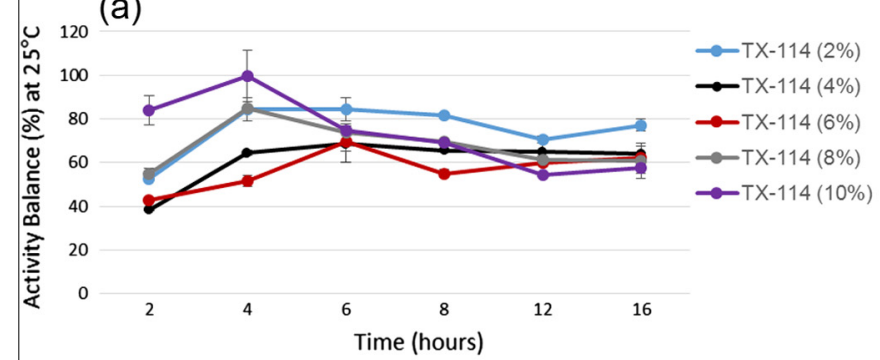

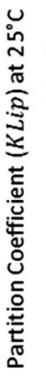

(b)

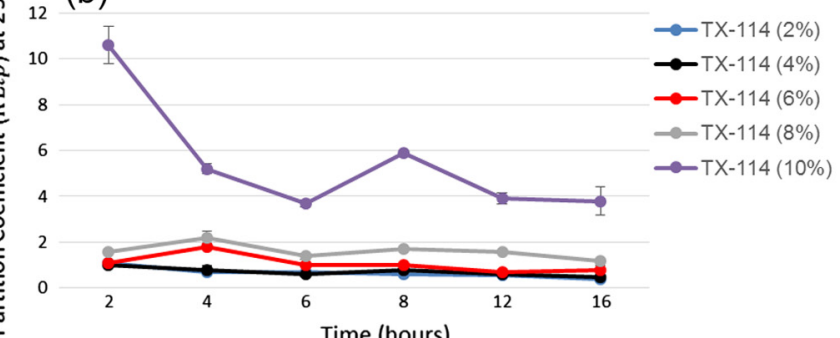

(c)

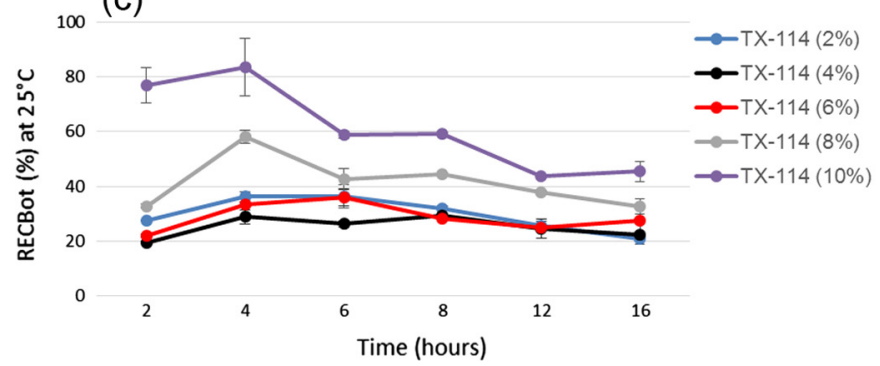

(d)
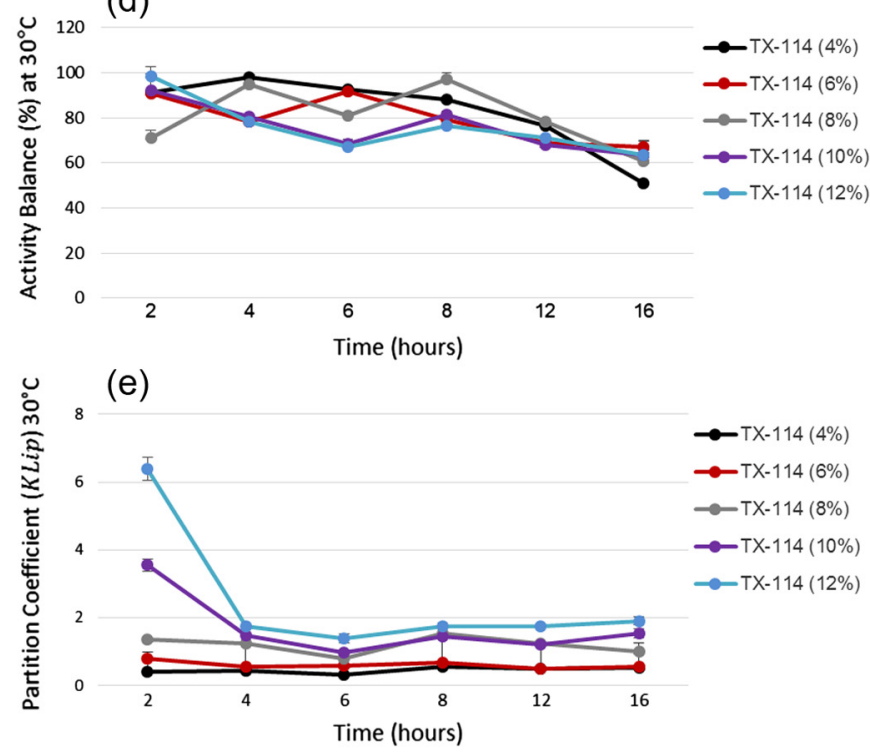

(f)

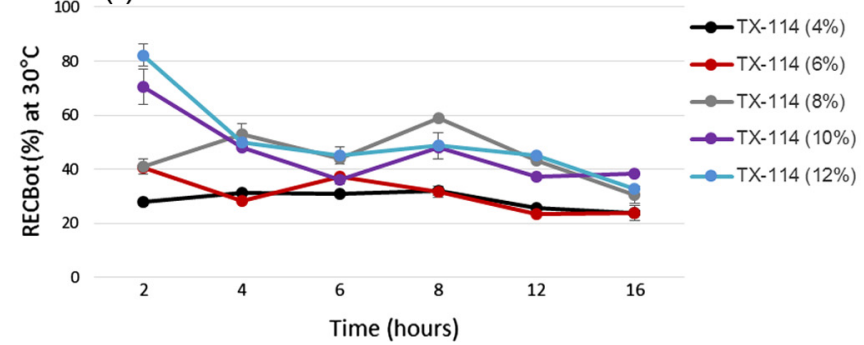

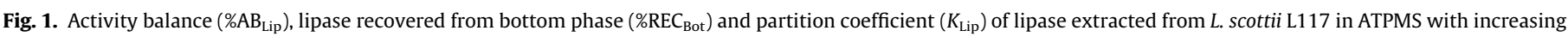

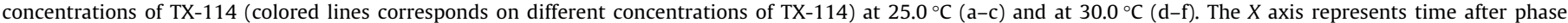

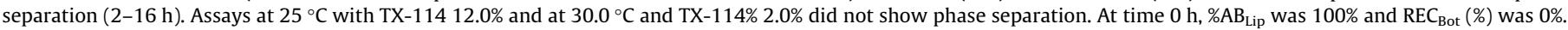
Experimental conditions: at 25 and $30.0^{\circ} \mathrm{C}, 7.0 \mathrm{pH}$ and $2.0-12 \% \mathrm{TX}-114$. Top phase (micelle-poor) and bottom phase (micelle-rich). 


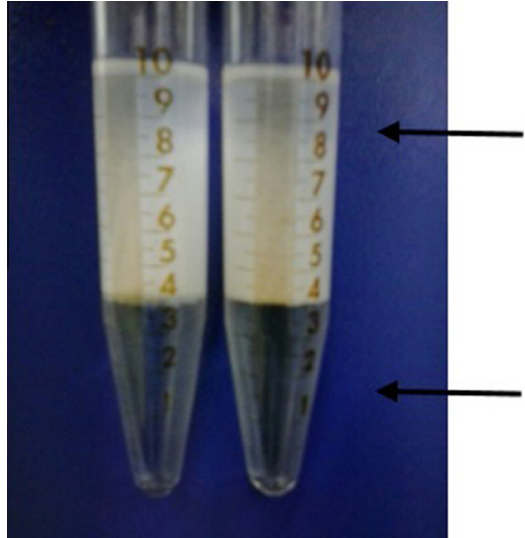

Top phase

(micelle-poor)

Bottom phase

(micelle-rich)

Fig. 2. Characterization of the ATPMS system including a micelle-rich phase with clear and transparent aspect, and a micelle-poor phase with yellow color and turbid aspect. Assay performed in validation condition. Experimental conditions: at $28.0{ }^{\circ} \mathrm{C}, 4.5 \mathrm{pH}$ and $8 \%$ of TX-114. (For interpretation of the references to color in this figure legend, the reader is referred to the web version of this article.)

an optimal activity level at $40{ }^{\circ} \mathrm{C}$ (Fig. 6). The $L$. scottii L117 lipase remained stable in the $\mathrm{pH}$ range from 3.0 to 8.0 and temperature range from $20.0^{\circ} \mathrm{C}$ to $45.0^{\circ} \mathrm{C}$, with relative residual lipase activity above $80 \%$ after $30 \mathrm{~min}$.

The synergistic effects of optimal temperature and $\mathrm{pH}$ values for lipase activity were determined by experimental design. According to the $\operatorname{CCD} 2^{2}$, the highest lipase activity would be reached at $47.1^{\circ} \mathrm{C}$ and $\mathrm{pH} 5.71\left(2.88 \mathrm{U} \mathrm{mL}^{-1}\right.$ assay 4 , Table 3$)$. Both $\mathrm{pH}$ and temperature had statistically significant effects $(p<0.05)$. The statistical significance of the analysis of optimal $\mathrm{pH}$ and temperature was confirmed by $F$ test (ANOVA). The $F$ value of 11.71 for the regression test was significant, i.e., greater than the tabulated $F$ value of 4.12 , and the model presented a good fit with the data $\left(R^{2}=87.0 \%\right.$, Supplementary material: Table 8$)$. Thus, we assumed the had good predictive value and used it to generate the contour plots and response surfaces shown in Fig. 7.

\section{Discussion}

Previous studies have evaluated lipase extraction utilizing different ATPS including PEG/salts [14,20,24,25], PEG/salts and imidazolium-based on ionic liquids as adjuvants [15], copolymer ethylene oxide-propylene oxide (EOPO) and potassium phosphate [12], ionic liquids and inorganic salts [30], and nonionic surfactants [10].

Lipase activity was evaluated in both phases in each ATPS system. Both ATPPS tested yielded lower \%AB $\mathrm{Aip}_{\text {Lip }}$, and we could only measure activity in the PEG-poor phase (Table 1). In the bottom phase, the enzyme may have been inactivated, which precludes the use of ATPPS for this specific lipase extraction in the conditions employed $(20.0 \% \mathrm{w} / \mathrm{w}$ of PEG 1500,4000 and 8000 and $20.0 \% \mathrm{w} / \mathrm{w}$ NaPA, $20.0 \% \mathrm{w} / \mathrm{w}$ phosphate salt, $\mathrm{pH}$ 7.0). Previous work showed that lipase from Bacillus sp. ITP-001 extracted with PEG/phosphate partitioned into the salt-rich phase, the results showed the best purification factor (201.53-fold) with PEG 8000 and potassium phosphate (20/18\%) with $6 \%$ of $\mathrm{NaCl}$ at $\mathrm{pH} 6.0$ [13].

The solubility of biomolecules is an important factor that should be taken into account, this effect in the salt-rich phase decreases with an increase in salt concentration, which results in increased partitioning of biomolecules to the PEG-rich phase by salting out effect [13]. Nonetheless, the volume exclusion effect at high PEG molecular weights was stronger than the salting out effect, in this study, and thus the enzyme remained partitioned more strongly to the salt-rich phase [13]. A similar pattern was observed by Khayati

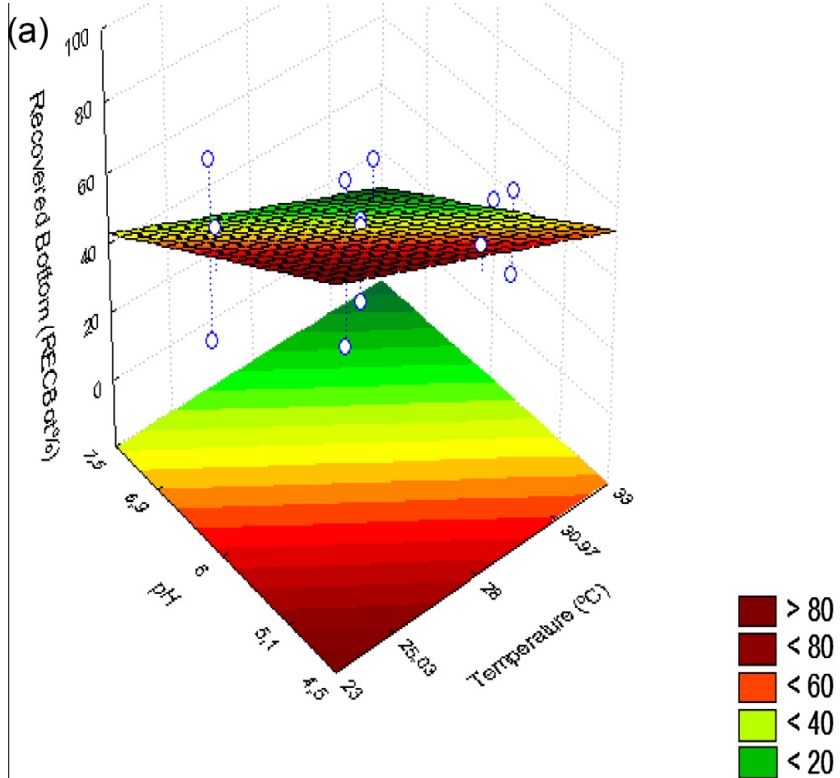

(b)

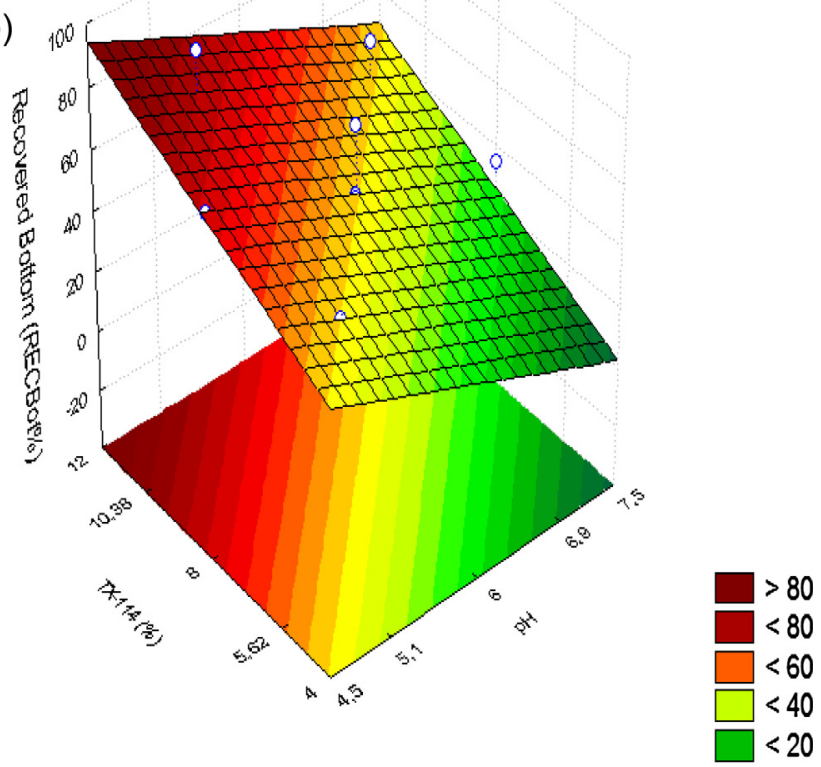

(c)
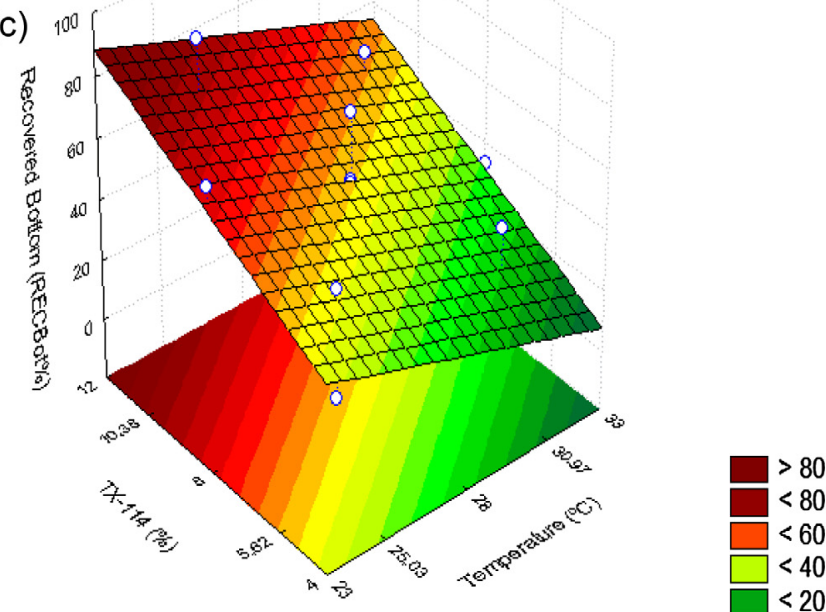

Fig. 3. Response surfaces for lipase recovered from the bottom phase (\%REC $\left.C_{\mathrm{Bot}}\right)$. Variables: (a) temperature vs. pH; (b) TX-114 vs. pH; and (c) pH vs. temperature. Experimental condition: temperature $23-33^{\circ} \mathrm{C}, 4.5-7.5 \mathrm{pH}$ and $4.0-12 \%$ of TX-114 Top phase (micelle-poor) and bottom phase (micelle-rich). 
(a)
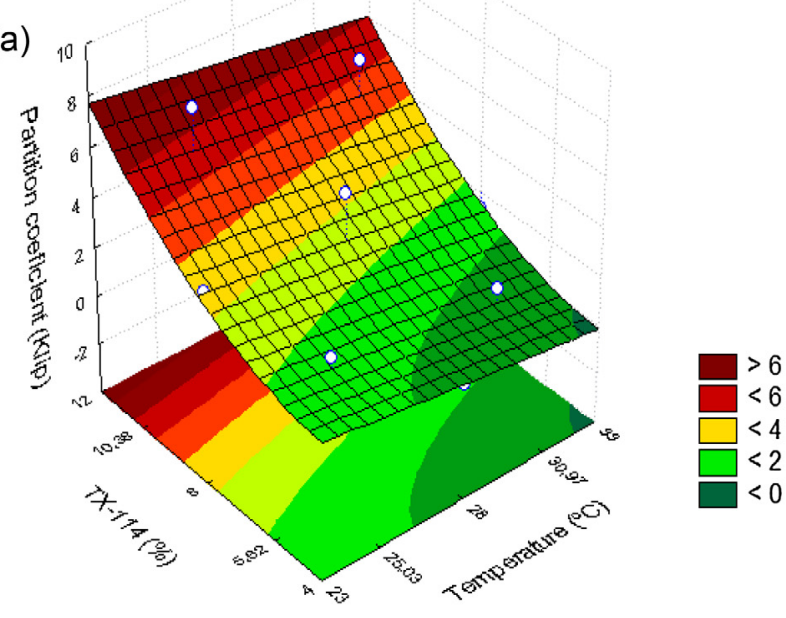

(b)
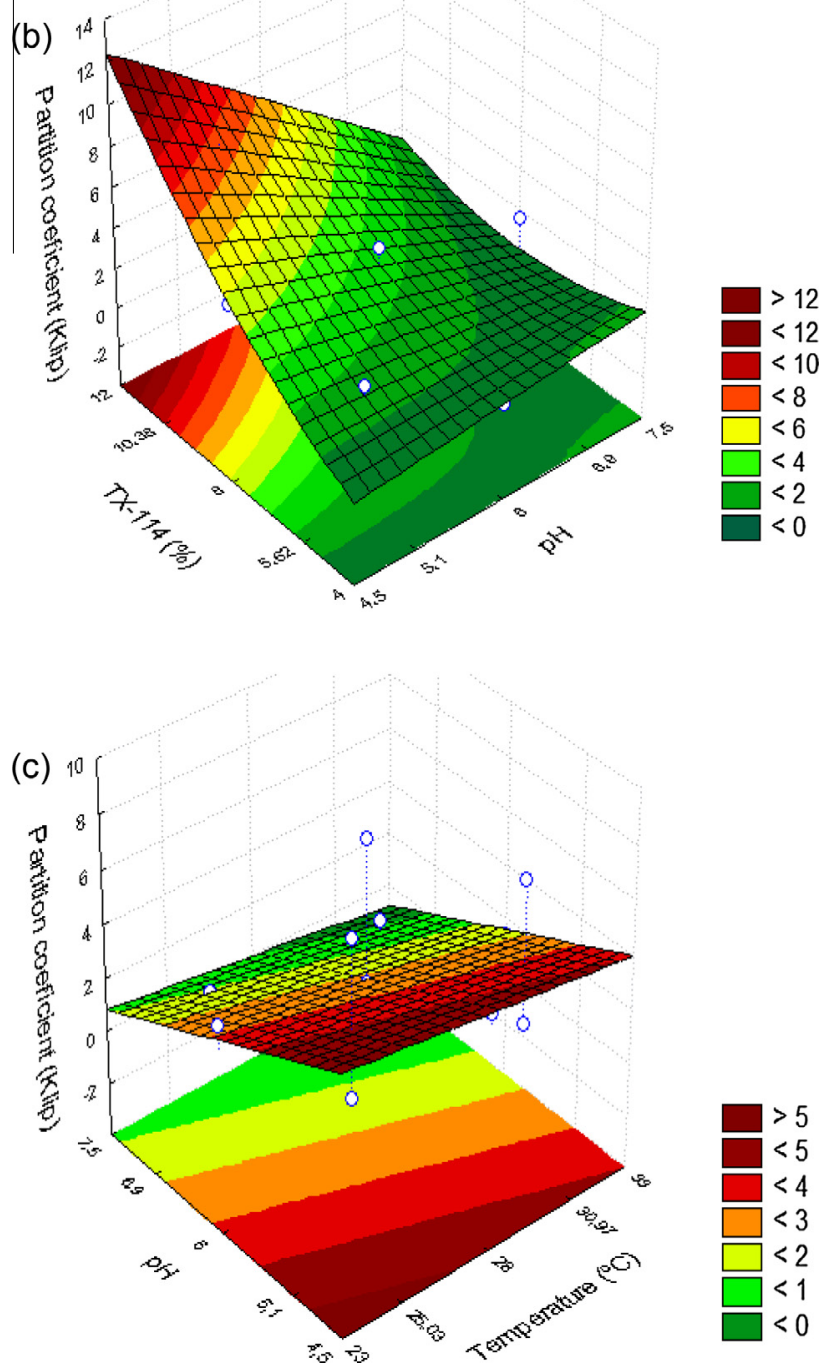

Fig. 4. Response surfaces for the response variable partition coefficient of lipase $\left(K_{\mathrm{Lip}}\right)$. Variables: (a) TX-114 vs. temperature; (b) TX-114 vs. $\mathrm{pH}$; and (c) pH vs. temperature. Experimental condition: temperature $23-33^{\circ} \mathrm{C}, 4.5-7.5 \mathrm{pH}$ and 4.0 $12 \%$ of TX-114. Top phase (micelle-poor) and bottom phase (micelle-rich).
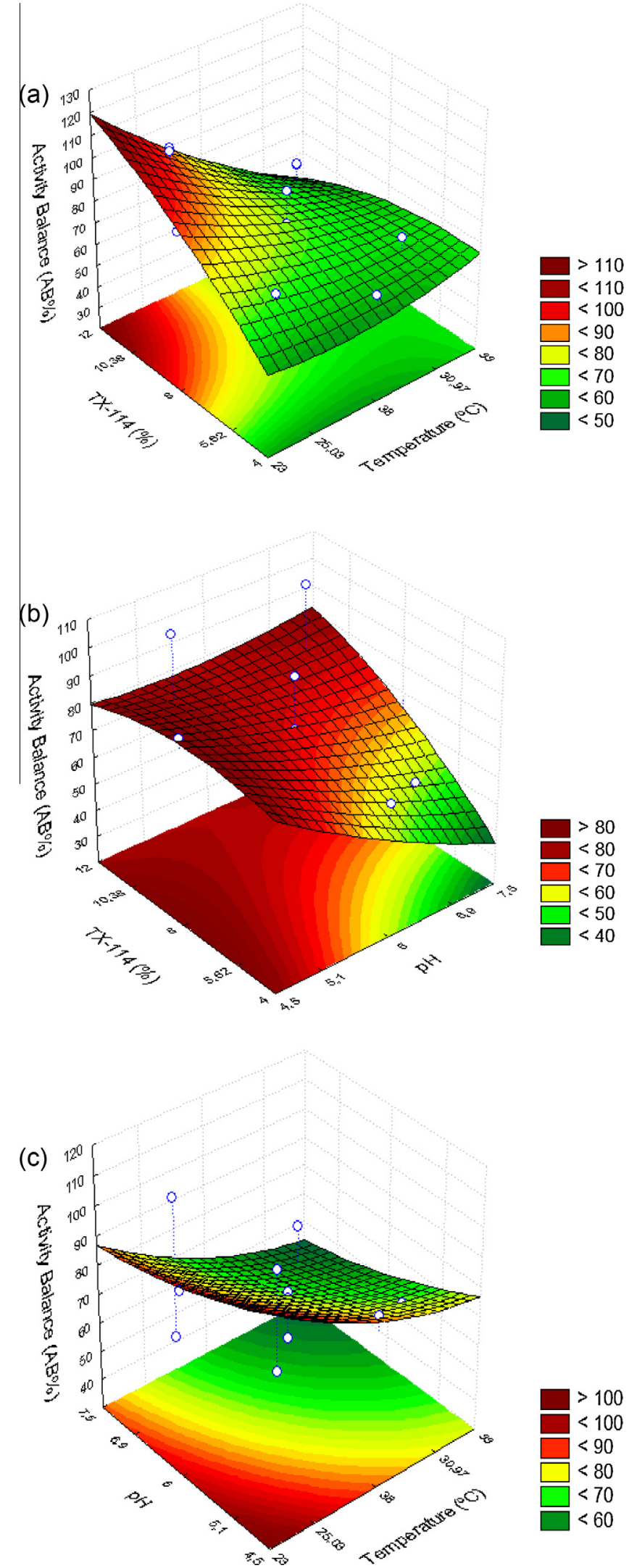

Fig. 5. Response surfaces for the response variable activity balance of lipase (\% $\mathrm{AB}_{\text {Lip }}$ ). Variables: (a) TX-114 vs. temperature; (b) TX-114 vs. $\mathrm{pH}$; and (c) pH vs. temperature. Experimental condition: temperature $23-33^{\circ} \mathrm{C}, 4.5-7.5 \mathrm{pH}$ and 4.0 $12 \%$ of TX-114. Top phase (micelle-poor) and bottom phase (micelle-rich). 

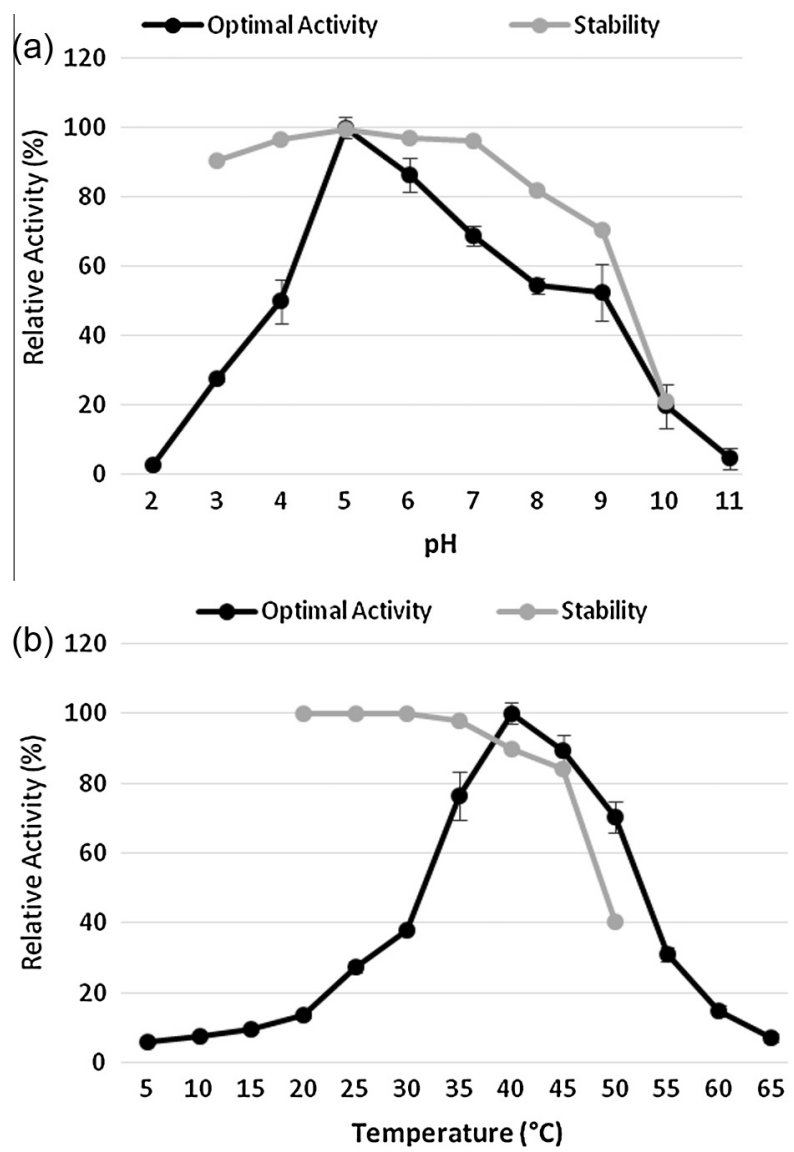

Fig. 6. Activity and stability of lipase derived from $L$. scottii L117 under different $\mathrm{pH}$ values (a) and temperatures (b). The pH assays were conducted at $25^{\circ} \mathrm{C}$ with $50 \mathrm{mM}$ buffers: glycine buffer $/ \mathrm{HCl}(\mathrm{pH} 2.0$ and 3.0), sodium citrate ( $\mathrm{pH} 4.0$ and 5.0), MES buffer ( $\mathrm{pH}$ 6.0), MOPSO buffer ( $\mathrm{pH} 7.0$ ), TAPS buffer ( $\mathrm{pH} 8.0$ and 9.0) and CAPS buffer ( $\mathrm{pH} 10.0$ and 11.0). The temperature assays were conducted with sodium citrate buffer ( $\mathrm{pH}$ 5.0). Assays were performed in triplicate.

and Alizadeh [14] in which study evaluated the partitioning of lipase from Rhodotorula glutinis in PEG/oxalate potassium and observed that the partition coefficient of lipase to top phase (PEG-rich) decreases $50 \%$ as the PEG molecular weight increases from PEG 4000 to PEG 8000 . Therefore, in polymeric system with PEG, excluded volume effect seems to have a important role in lipase partition.

The \% $\mathrm{AB}_{\text {Lip }}$ of $L$. scottii $\mathrm{L} 117$ lipase ranged between $84.7 \%$ and $113 \%$ at 25.0 and $28.0^{\circ} \mathrm{C}$ in preliminary assays with the micellar system. An $\% \mathrm{AB}_{\text {Lip }}$ loss of $15 \%$ is considered acceptable in ATPS purification processes [31], therefore, we proceeded with our assessments using the nonionic surfactant TX-114 system for $L$. scottii L117 lipase extraction. The high $113.0 \%$ value may be related

Table 3

Matrix of the central composite design ( $C C D 2^{2}$ ) used to determine the ideal temperature and $\mathrm{pH}$ for lipase acitivity.

\begin{tabular}{clll}
\hline Assays & $T\left({ }^{\circ} \mathrm{C}\right)$ & $\mathrm{pH}$ & Lipase activity $\left(\mathrm{U} \mathrm{mL}^{-1}\right)$ \\
\hline 1 & $-1(32.9)$ & $-1(4.29)$ & 1.858 \\
2 & $1(47.1)$ & $-1(4.29)$ & 2.003 \\
3 & $-1(32.9)$ & $1(5.71)$ & 1.694 \\
4 & $1(47.1)$ & $1(5.71)$ & 2.887 \\
5 & $-1.41(30.0)$ & $0(5.0)$ & 1.054 \\
6 & $1.41(50.0)$ & $0(5.0)$ & 2.067 \\
7 & $0(40.0)$ & $-1.41(4.0)$ & 2.039 \\
8 & $0(40.0)$ & $1.41(6.0)$ & 1.994 \\
9 & $0(40.0)$ & $0(5.0)$ & 2.468 \\
10 & $0(40.0)$ & $0(5.0)$ & 2.564 \\
11 & $0(40.0)$ & $0(5.0)$ & 2.531 \\
12 & $0(40.0)$ & $0(5.0)$ & 2.564
\end{tabular}

to a decrease in lipase inhibitor concentrations. In the preliminary assay, lipase partitioned to the top phase with 2.6 and $3.6 \mathrm{U} \mathrm{mL}^{-1}$ at 25.0 and $28.0^{\circ} \mathrm{C}$, respectively, and bottom phase with 1.96 and $2.47 \mathrm{U} \mathrm{mL}^{-1}$ at 25.0 and $28.0^{\circ} \mathrm{C}$, respectively, both at $\mathrm{pH}$ 7. The micelle-poor phase showed a turbid aspect, while the micellerich phase was clear and free of compounds typically present in acetone and ethanol precipitation, which would hamper the application of classical chromatographic systems. We, thus, optimized the micellar system for greater lipase recovery from the micellerich phase and partition coefficient $\left(K_{\mathrm{Lip}}\right)$ increased by 10.3 -fold (0.75-7.76).

Lipases have many hydrophobic residues that possibly influence partition to the more hydrophobic phase in ATPS [10,32]. Lipases produced by prokaryote preferentially partitioned to the micelle-rich phase because of it hydrophobicity. This affinity may be a reflection of hydrophobic interaction between micelle core and hydrophobic lipase surface [10]. In ATPMS, when the surfactant reaches a critical micelle concentration (CMC), micelles form in the aqueous solution following different geometric organizations such as lamellar, spherical, cubical, and planar [10,16,31], and polymeric system arrange themselves with different exclusion volume effect characteristics among system conditions and types.

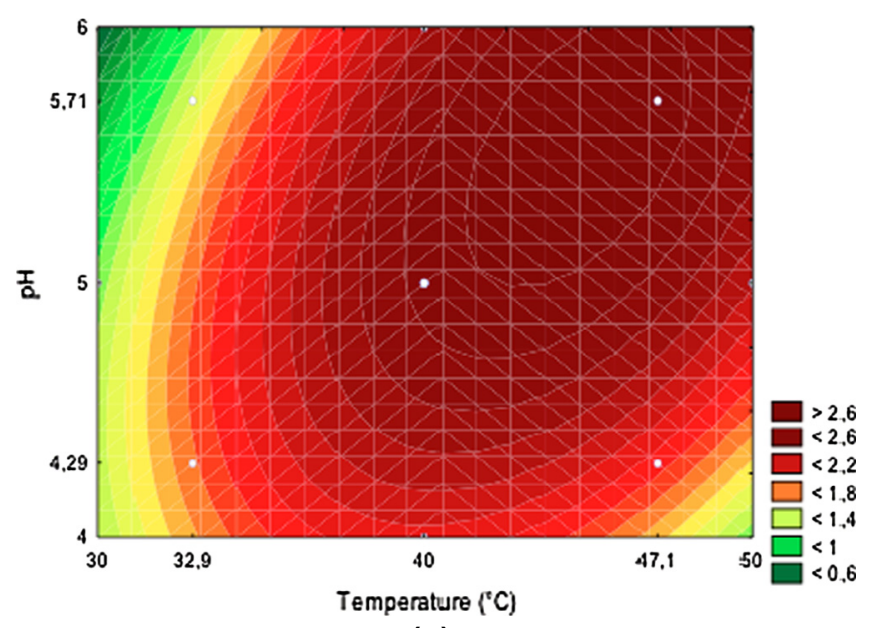

(a)

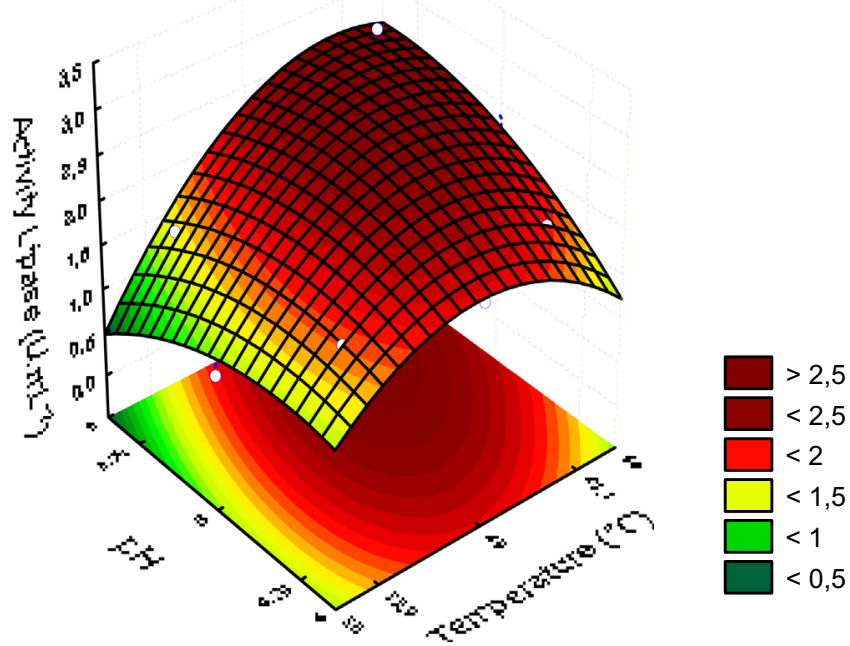

(b)

Fig. 7. Contour (a) and response surface (b) of $\mathrm{pH}$ versus temperature for lipase activity of L. scottii L117. 
Therefore, polymeric and micellar system present different available volume to molecules partition. As discuss above, polymeric system exclusion volume effects are important in lipase partitioning in these systems $[13,14]$. In our results, exclusion volume effect seems to have a minor effect when compared with hydrophobicity interaction between micelles and lipases in ATPMS. Yeast lipases usually have molecular weight ranging between $\sim 33$ and $\sim 65 \mathrm{kD}$ [1], however lipase produced by Candida utilis showed 90110 kDa [33] and Kluyveromyces lactis showed 160-250 kDa [34]. Therefore, it is important to determine experimentally the best system for each molecule, since size and aminoacid composition varies. In general, ATPS and ATPMS suit biological samples because each phase contains $60-90 \%$ water, providing a mild environment for active molecules $[11,16,23]$, and in our results ATPMS presented the best system.

In order to further characterize the application of this ATPMS we tested enzymatic stability at two different temperatures (25.0 and $30.0^{\circ} \mathrm{C}$ ), with different extraction times $(2,4,6,8,12$ and $16 \mathrm{~h}$ ), different $\mathrm{TX}-114$ concentrations $(2.0 \%, 4.0 \%, 6.0 \%, 8.0 \%$, $10.0 \%$ and $12.0 \% \mathrm{w} / \mathrm{w}$ ) and different response variables were evaluated: \% $\mathrm{AB}_{\text {Lip }}, K_{\text {Lip }}$ and \%REC $C_{\text {Bot. }}$ The \% $\mathrm{AB}_{\text {Lip }}$ after $6 \mathrm{~h}$ at $25.0{ }^{\circ} \mathrm{C}$ was stable especially at higher TX-114 concentrations (Fig. 1). However, these values varied with time, and $\% \mathrm{AB}_{\mathrm{Lip}}$ tended to remain higher for longer at a temperature of $30.0^{\circ} \mathrm{C}$. The lipase remained fairly stable, even at high TX-114 concentrations, for longer periods, and at the highest temperature tested.

After optimizing the system for $\mathrm{pH}$, temperature and TX-114 concentration, the best extraction conditions were at low $\mathrm{pH}$ and temperature values and higher TX-114 concentration. Increases in $\mathrm{pH}$ had a negative effect on the partition of lipase $(p<0.05)$, i.e., the lower $\mathrm{pH}$ values correlated with better extraction. In fact, the best condition was at the lowest $\mathrm{pH}$ limit (4.5) in assay 11 of the first experimental design, which displayed an $\% \mathrm{AB}_{\text {Lip }}$ of $88.94 \%, K_{\text {Lip }}$ of 4.77 , specific activity of $2.04 \mathrm{U} / \mathrm{mg}$ and PF of 1.97 (Table 2). A different pattern was observed when $\mathrm{pH}$ was decreased from 9.0 to 6.0 reducing lipase yield from $92.16 \%$ to $36.22 \%$ and PF from 1.85 to 0.86 for lipase produced by Aspergillus niger with a PEG/phosphate system [35]. This reduction may result from low lipase stability at lower $\mathrm{pH}$ levels. In addition, this enzyme had alkaline lipase characteristics and had an optimal $\mathrm{pH}$ range for activity between 7.0 and 9.0. During ATPS extraction, the pH can affect the charge of chemical groups present on amino acids side chains, modifying the net global charge of proteins. The number of charged groups on the protein molecule surface varies with $\mathrm{pH}$, which results in modifications in protein structure and its intercalations with polymers and micelles [16,31].

Temperature also inversely correlated with $L$. scottii L117 lipase extraction, and the best assays were performed at 25.0 and $28.0^{\circ} \mathrm{C}$ (Table 2). Phase separation is induced by a shift in temperature and nonionic surfactant concentration, therefore the TX-114 system displays such temperature-sensitive phase separation, and can form cloud point extraction systems in specific combinations of these parameters. TX-114 has a relatively low clouding point at approximately $22.0^{\circ} \mathrm{C}$, and separates into the micelle-rich detergent phase and micelle-poor aqueous phase at temperatures above this clouding point [16].

TX-114 concentration positively correlated with \% $\mathrm{AB}_{\mathrm{Lip}}$, \% $\mathrm{REC}_{\mathrm{Bot}}$ and $K_{\text {Lip. }}$. Similar result was observed by Ooi et al. [10] who evaluated the extraction of lipase produced by Burkholderia sp. ST8 with TX-114 and several members of the pluronic series (triblock copolymers L31, L61, L81 and L121), ranging between 5\% and $20 \%(w / w)$. The pluronic L81 displayed optimal partition efficiency for the recovery of lipase from the micellar phase of the ATPMS when compared to the other surfactant agents. In ATPMS consisting of the highest $\mathrm{L} 81$ concentration and $0.5 \%(\mathrm{w} / \mathrm{w})$ of $\mathrm{KCl}$, lipase preferentially separated to the micelle-rich phase and purification increased by 7.2-fold. The lipase was recovered in bottom phase with the yield of $89 \%$ and partition coefficient of 0.34 .

On the other hand, hydrophilic proteins (alkaline protease, lysozyme, pyruvated decarboxylase, bovine serum albumin) exhibited poor partitioning into the detergent-rich phase with $K$-values near 1.0 in a C14-based system [36]. Nonionic surfactants have been used to solubilize proteins that are membrane-associated without loss of their biological activity. During solubilization, the nonionic surfactant replaces most lipid molecules in contact with the hydrophobic domain of the amphiphilic protein and leads to the formation of a soluble protein-surfactant mixed micelle [16].

The difference between the physicochemical environments in the micelle-rich and in the micelle-poor phases forms the basis for an effective separation and makes ATPMS a convenient and potentially useful method for the separation, purification and concentration of biomaterials [31]. According to our results, the micellar system was the most suitable method for lipase extraction produced by $L$. scottii L117. Nevertheless, improvements may be achieved by studying other parameter in APTMS extraction of this lipase, such as the use of varying salts in the formulation. Early members of the Hofmeister series could lead to a greater salting out effect increasing partitioning of lipase to micellar rich phase, increasing solvent surface tension [37,38]. Interestingly, APTMS can be applied in extractive fermentation, and was indeed used before presenting interesting results (4.2-fold concentration and 1.3-fold in purification factor) [39], a similar approach can be used, using the results obtained so far to guide these next step.

Other methods can be used for the purification of lipases, such as reverse micellar extraction, with interest results (15-fold purification, $80 \%$ recovery and 2.5 -fold concentration), nevertheless this approach uses large volumes os organic solvents which would require reutilization or waste treatment [40]. Another possible method is ionic liquids extraction, which is a new approach, but still need more studies to demonstrate its applicability. Currently, there are few studies in this area, although lipase extraction was evaluated, but from a commercial source [40]. A traditional method used is precipitation, which gives a high average yield $\sim 85 \%$, have interesting characteristics as ATPMS, easily scalable, low interference of non-protein materials. Nevertheless, as ATPMS, it must be used in early purification steps follow by chromatographic steps [41]. Chromatographic steps, on other hand, require crude separation steps in order to remove non-protein contaminants, but generate high purification folds per step, although yield generally are low [41].

A crude lipase extract was evaluated to define the optimum $\mathrm{pH}$ and temperature, and yielded results consistent with an acid lipase (optimum $\mathrm{pH}$ 5.0). Yeasts usually express alkaline lipases $[1,42]$, although Candida viswanathii does express a lipase with an optimum pH of 3.5 and stability in acidic conditions after $24 \mathrm{~h}$ [43].

Although L. scottii L117 was isolated from Antarctic marine sediments, its lipase reached optimal activity at $40^{\circ} \mathrm{C}$. The lipase remained stable in $\mathrm{pH}$ values ranging from $\mathrm{pH} 3.0$ to 8.0 and temperatures from 20.0 to $45.0^{\circ} \mathrm{C}$, with relative residual lipase activity above $80 \%$ after $30 \mathrm{~min}$ of incubation. These results have important consequences for the potential uses of this enzyme. Other lipases produced by Antartic microorganisms also displayed high optimal temperatures, in particular the thermostable lipase B (CalB) produced by Pseudozyma antarctica [44]. Lipase produced by Bacillus pumillus isolated from Antarctic soil samples had optimal activity temperature of $40^{\circ} \mathrm{C}[45]$.

\section{Conclusion}

Purification of lipase from unclarified cultures of L. scottii L117 was more efficient with an ATPMS. Lipase preferentially parti- 
tioned into the micelle-rich phase $\left(K_{\mathrm{Lip}}=7.76\right.$ and 4.77 , \% $\mathrm{REC}_{\mathrm{Bot}}=93.85 \%$ and $73.53 \%$ and $\mathrm{PF}=1.2$ and 1.97 ), indicating that the ATPMS represents an alternative to purification/extraction of lipase $L$. scottii L117.

To maximize enzyme recovery, we recommend shorter partition times, which in addition to yielding higher $K_{\mathrm{Lip}}$, generate lower operation costs. Interestingly, values of $\% \mathrm{AB}_{\mathrm{Lip}}, K_{\mathrm{Lip}}$ and $\% \mathrm{REC}_{\mathrm{Bot}}$ obtained at $25^{\circ} \mathrm{C}$ were relatively higher than at $30^{\circ} \mathrm{C}$, indicating that partitions can be performed at room temperature. Altogether, our results point to a highly recommended system for the purification of lipase from $L$. scottii L117, and with potential to be adapted for other labile biomolecules. The simplicity of ATPMS in the extraction/purification of lipase from unclarified broth produced by $L$. scotti L117 is differential in this approach.

\section{Acknowledgements}

This research was supported by grants from the Coordination for Higher Level Graduate Improvements (CAPES/Brazil), the National Council for Scientific and Technological Development (CNPq/Brazil) and the São Paulo Research Foundation (FAPESP/Brazil, \#2010/08352-5, \#2010/17033-0 and \#2013/19486-0).

\section{Appendix A. Supplementary material}

Supplementary data associated with this article can be found, in the online version, at http://dx.doi.org/10.1016/j.seppur.2015.10. 001.

\section{References}

[1] J. Vakhlu, A. Kour, Yeast lipases: enzyme purification, biochemical properties and gene cloning, Electron. J. Biotechnol. 9 (2006) 69-85, http://dx.doi.org/ 10.2225/vol9-issue1-fulltext-9.

[2] A.K. Singh, M. Mukhopadhyay, Overview of fungal lipase: a review, Appl. Biochem. Biotechnol. 166 (2012) 486-520, http://dx.doi.org/10.1007/s12010011-9444-3.

[3] B. Joseph, P.W. Ramteke, G. Thomas, Cold active microbial lipases: some hot issues and recent developments, Biotechnol. Adv. 26 (2008) 457-470, http:// dx.doi.org/10.1016/j.biotechadv.2008.05.003.

[4] D.M. Lan, N. Yang, W.K. Wang, Y.F. Shen, B. Yang, Y.H. Wang, A novel coldactive lipase from Candida albicans: cloning, expression and characterization of the recombinant enzyme, Int. J. Mol. Sci. 12 (2011) 3950-3965, http://dx.doi. org/10.3390/ijms12063950.

[5] X. Li, W. Zhang, Y. Wang, Y. Dai, H. Zhang, Y. Wang, H. Wang, A high-detergentperformance, cold-adapted lipase from Pseudomonas stutzeri PS59 suitable for detergent formulation, J. Mol. Catal. B - Enzym. 102 (2014) 16-24, http://dx. doi.org/10.1016/j.molcatb.2014.01.006.

[6] C. Gerday, M. Aittaleb, M. Bentahir, J. Chessa, P. Claverie, T. Collins, S. D’amico, J. Dumont, G. Garsoux, D. Georlette, A. Hoyoux, T. Lonhienne, M. Meuwis, G. Feller, Cold-adapted enzymes: from fundamentals to biotechnology, Trends Biotechnol. 18 (2000) 103-107, http://dx.doi.org/10.1016/S0167-7799(99) 01413-4.

[7] K.E. Jaeger, T. Eggert, Lipases for biotechnology, Curr. Opin. Biotechnol. 13 (2002) 390-397, http://dx.doi.org/10.1016/s0958-1669(02)00341-5.

[8] S. Kumar, A. Mathur, V. Singh, S. Nandy, S.K. Khare, S. Negi, Bioremediation of waste cooking oil using a novel lipase produced by Penicillium chrysogenum SNP5 grown in solid medium containing waste grease, Bioresour. Technol. 120 (2012) 300-304, http://dx.doi.org/10.1016/j.biortech.2012.06.018.

[9] D. Sharma, B. Sharma, A.K. Shukla, Biotechnological approach of microbial lipase: a review, Biotechnology 10 (2011) 23-40, http://dx.doi.org/10.3923/ biotech.2011.23.40.

[10] C.W. Ooi, C.P. Tan, S.L. Hii, A. Ariff, S. Ibrahim, T.C. Ling, Primary recovery of lipase derived from Burkholderia sp. ST8 with aqueous micellar two-phase system, Process Biochem. 46 (2011) 1846-1852, http://dx.doi.org/10.1016/j. procbio.2011.06.014.

[11] Y.L. Zhou, C.L. Hu, N. Wang, W.W. Zhang, X.Q. Yu, Purification of porcine pancreatic lipase by aqueous two-phase systems of polyethylene glycol and potassium phosphate, J. Chromatogr. B Anal. Technol. Biomed. Life Sci. 926 (2013) 77-82, http://dx.doi.org/10.1016/j.jchromb.2013.03.005.

[12] P.L. Show, C.P. Tan, M.S. Anual, A. Ariff, Y.A. Yosof, S.K. Chen, T.C. Ling, Primary recovery of lipase derived from Burkholderia cenocepacia strain ST8 and recycling of phase components in an aqueous two-phase system, Biochem. Eng. J. 60 (2012) 74-80, http://dx.doi.org/10.1016/j.bej.2011.10.005.

[13] J.M.P. Barbosa, R.L. Souza, A.T. Fricks, G.M. Zanin, C.M.F. Soares, A.S. Lima, Purification of lipase produced by a new source of Bacillus in submerged fermentation using an aqueous two-phase system, J. Chromatogr. B 879 (2011) 3853-3858, http://dx.doi.org/10.1016/j.jchromb.2011.10.035.

[14] G. Khayati, A. Alizadeh, Extraction of lipase from Rhodotorula glutinis fermentation culture by aqueous two-phase partitioning, Fluid Phase Equilib. 353 (2013) 132-134, http://dx.doi.org/10.1016/j.fluid.2013.05.037.

[15] R.L. Souza, S.P.M. Ventura, C. Soares, J.A.P. Coutinho, A. Lima, Lipase purification using ionic liquids as adjuvants in aqueous two-phase systems, Green Chem. (2015), http://dx.doi.org/10.1039/C5GC00262A.

[16] E. Besel, Use of Triton-X114 aqueous two phase system for recovery of mushroom (Agaricus bisporus) polyphenoloxidase, Dissertation, The Middle East Technical University, Turkey, 2003.

[17] P.G. Mazzola, A.M. Lopes, F.A. Hasman, A.F. Jozala, T.C.V. Penna, P.O Magalhaes, C.O. Rangel-Yagui, A. Pessoa-Jr, Liquid-liquid extraction of biomolecules: an overview and update on the main techniques, J. Chem. Technol. Biotechnol. 83 (2008) 143-157, http://dx.doi.org/10.1002/jctb.1794.

[18] S. Freitas, S. Canário, J.A. Santos, D.M. Prazeres, Alternatives for the intermediate recovery of plasmid DNA: performance, economic viability and environmental impact, Biotechnol J 4 (2009) 265-278, http://dx.doi.org/ 10.1002/biot.200800216.

[19] R.B. Haga, V.C. Santos-Ebinuma, M.S.C. Silva, A. Pessoa, C.O. Rangel-Yagui, Clavulcanic acid partitioning in charged aqueous two-phase micellar systems, Sep Purif Technol 103 (2013) 273-278, http://dx.doi.org/10.1016/j. seppur.2012.10.034.

[20] C.H. Ooi, B.T. Tey, S.L. Hii, A. Ariff, H.S. Wu, J.C.W. Lan, R.S. Juang, S.M.M. Kamal, T.C. Ling, Direct purification of Burkholderia pseudomallei lipase from fermentation broth using aqueous two-phase system, Biotechnol Bioprocess Eng 14 (2009) 811-818, http://dx.doi.org/10.1007/s12257-008-0306-y.

[21] J.V.D. Molino, V.A. Feitosa, L.C.L. Novaes, V.C. Santos-Ebinuma, A.M. Lopes, A.F. Josala, D.A. Viana, L.M. Pellegrini, A. Pessoa-Jr, Biomolecules and bioparticles purification processes: an overview, Rev. Mex. Ing. Quim. 13 (2014) 359-377.

[22] M. Garza-madrid, M. Rito-Palomares, S.O. Serna-Saldivar, J. Benavides, Potential of aqueous two-phase system constructed on flexible devices: human sérum albumin as proof of concept, Process Biochem. 45 (2010) 10821087, http://dx.doi.org/10.1016/j.procbio.2010.03.026.

[23] X. Wang, X. Wei, J. Liu, J. Liu, D. Sun, P. Du, A. Ping, Study on the aqueous twophase systems composed of surfactant, ionic liquid and water, Fluid Phase Equilib. 347 (2013) 1-7, http://dx.doi.org/10.1016/j.fluid.2013.03.004.

[24] G.S. Padilha, J.C.C. Santana, R.M. Alegre, E.B. Tambourgi, Extraction of lipase from Burkholderia cepacia by PEG/Phosphate ATPS and Its biochemical characterization, Brazilian Arch. Biol. Technol. 55 (2012) 7-19, http://dx.doi. org/10.1590/S1516-89132012000100002.

[25] R.L. Souza, J.M. Barbosa, G.M. Zanin, M.W. Lobao, C.M. Soares, A.S. Lima, Partitioning of porcine pancreatic lipase in a two-phase systems of polyethylene glycol/potassium phosphate aqueous, Appl. Biochem. Biotechnol. 161 (2010) 288-300, http://dx.doi.org/10.1007/s12010-0108907-2.

[26] A.F.W. Duarte, I. Dayo-Owoyemi, F.S. Nobre, F.C. Pagnocca, L.C.S. Chaud, A Pessoa, M.G.A. Felipe, L.D. Sette, Taxonomic assessment and enzymes production by yeasts isolated from marine and terrestrial Antarctic samples, Extremophiles 17 (2013) 1023-1035, http://dx.doi.org/10.1007/s00792-0130584-y.

[27] J.F.B. Pereira, V.C. Santos, H.O. Johansson, J.A. Teixeira, A. Pessoa, A stable liquid-liquid extraction system for clavulanic acid using polymer-based aqueous two-phase systems, Sep. Purif. Technol. 98 (2012) 441-450, http:// dx.doi.org/10.1016/j.seppur.2012.08.008.

[28] A.F. Jozala, A.M. Lopes, L.C. de Lencastre Novaes, P.G. Mazzola, T.C.V. Penna, A. P. Júnior, Aqueous two-phase micellar system for nisin extraction in the presence of electrolytes, Food Bioprocess Technol. 6 (2013) 3456-3461, http:/ dx.doi.org/10.1007/s11947-012-1008-1.

[29] StatSoft Inc, STATISTICA for Windows [Computer program manual], Tulsa, OK, 1995.

[30] S.P.M. Ventura, G.S. Souza, M.G. Freire, L.S. Serafim, A.S. Lima, J.A.P. Coutinho, Design of ionic liquids for lipase purification, J. Chromatogr. B 879 (2011) 2679-2687, http://dx.doi.org/10.1016/j.jchromb.2011.07.022.

[31] A.M. Lopes, V.C. Santos-Ebinuma, A. Pessoa-Jr, C.O. Rangel-Yagui, Influence of salts on the coexistence curve and protein partitioning in nonionic aqueous two-phase micellar systems, Brazilian J. Chem. Eng. 31 (2014) 1057-1064, http://dx.doi.org/10.1590/0104-6632.20140314s00002677.

[32] T. Minuth, Extraction of amphiphilic proteins using detergent-based aqueous two-phase systems. In: R. Hatti-Kaul (Ed.), Methods in Biotechnology, 11th ed., Lund, Sweden, 2008, pp. 291-302.

[33] S. Fujino, D. Akiyama, S. Akaboshi, T. Fujita, Y. Watanabe, Y. Tamai, Purification and characterization of Phospholipase B from Candida utilis, Biosci. Biotechnol. Biochem. 70 (2006) 377-386, http://dx.doi.org/10.1271/bbb.70.377.

[34] H. Oishi, T. Morimoto, Y. Watanabe, Y. Tamai, Purification and characterization of phospholipase B from Kluyveromyces lactis and cloning of phospholipase B gene, Biosci. Biotechnol. Biochem. 63 (1999) 83-90, http://dx.doi.org/10.1271/ bbb.63.83.

[35] K.E. Nandini, N.K. Rastogi, Liquid-liquid extraction of lipase using aqueous two-phase system, Food Bioprocess Technol. 4 (2011) 295-303, http://dx.doi. org/10.1007/s11947-008-0160-0.

[36] G.C. Terstappen, R.A. Ramelmeier, M.R. Kula, Protein partitioning in detergentbased aqueous two-phase systems, J. Biotechnol. 28 (1993) 263-275, http:// dx.doi.org/10.1016/0168-1656(93)90175-M.

[37] H.O. Johansson, M. Ishi, M. Minaguti, E. Feitosa, T.C.V. Penna, A. Pessoa, Separation and partitioning of green fluorescent protein from Escherichia coli 
homogenate in poly(ethylene glycol)/sodium-poly(acrylate) aqueous twophase systems, Sep. Purif. Technol. 62 (2008) 166-174, http://dx.doi.org/ 10.1016/j.seppur.2008.01.017.

[38] F. Luechau, T.C. Ling, A. Lyddiatt, Recovery of B19 virus-like particles by aqueous two-phase systems, Food Bioprod. Process. 89 (2011) 322-327, http://dx.doi.org/10.1016/j.fbp.2010.10.008.

[39] T. Pan, Z. Wang, J.H. Xu, Z. Wu, H. Qi, Extractive fermentation in cloud point system for lipase production by Serratia marcescens ECU1010, Appl. Microbiol. Biotechnol. 85 (2010) 1789-1796, http://dx.doi.org/10.1007/s00253-0092257-4.

[40] R.P. Gaikaiwari, S.A. Wagh, B.D. Kulkarni, Efficient lipase purification using reverse micellar extraction, Bioresour. Technol. 108 (2012) 224-230, http://dx. doi.org/10.1016/j.biortech.2011.11.126.

[41] R.K. Saxena, A. Sheoran, B. Giri, W.S. Davidson, Purification strategies for microbial lipases, J. Microbiol. Meth. 52 (2003) 1-18, http://dx.doi.org/ 10.1016/S0167-7012(02)00161-6.
[42] I. Bataiche, N. Kacem-Chaouche, J. Destain, A. Lejeune, P. Thonart, Screening of Candida boidinii Chemlal spent olive characterized by higher alkaline-cold adapted lipase production, Afr. J. Biotechnol. 12 (2014) 1287-1294, http://dx. doi.org/10.5897/AJB2013.13586.

[43] A.F. Almeida, S.M. Tauk-Tornisielo, E.C. Carmona, Acid lipase from Candida viswanathii: production, biochemical properties, and potential application, BioMed Res. Int. (2013) 435818, http://dx.doi.org/10.1155/2013/435818.

[44] Y. Poojari, S.J. Clarson, Thermal stability of Candida antarctica lipase B immobilized on macroporous acrylic resin particles in organic media, Biocatal. Agric. Biotechnol. 2 (2012) 7-11, http://dx.doi.org/10.1016/j. bcab.2012.10.002.

[45] A.R. Arifin, S.J. Kim, J.H. Yim, A. Suwanto, H.K. Kim, Isolation and biochemical characterization of Bacillus pumilus lipases from the Antarctic, J. Microbiol. Biotechnol. 23 (2013) 661-667, http://dx.doi.org/10.4014/jmb.1212.12040. 